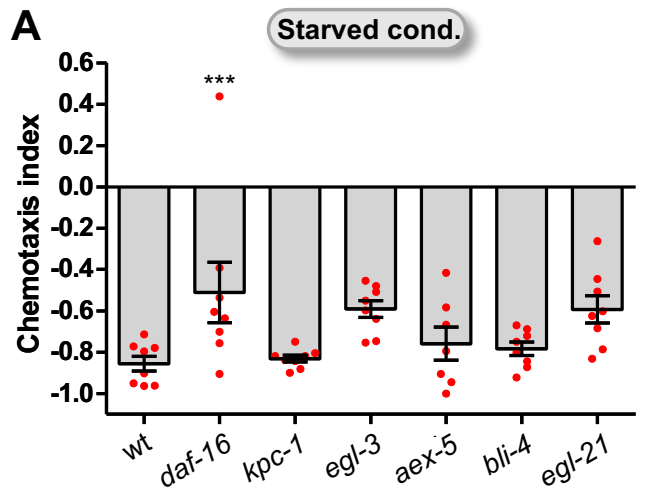

C

\section{Fed cond.}

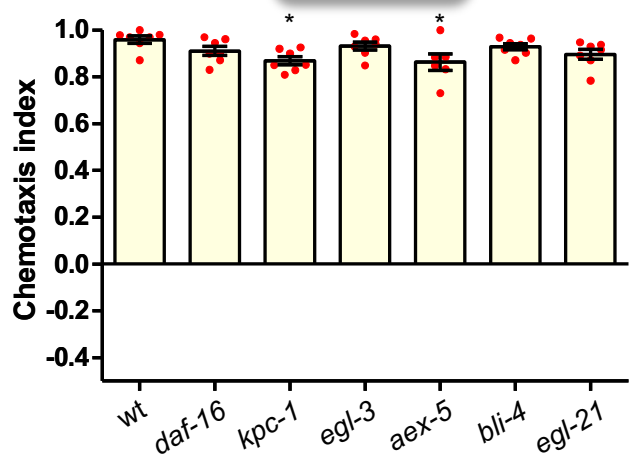

E

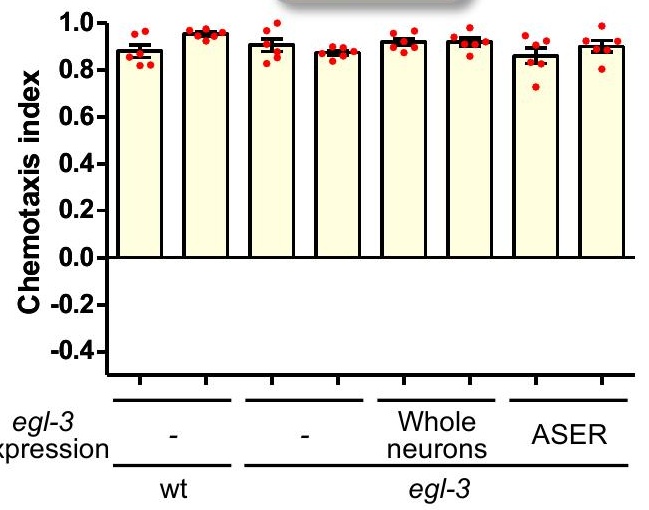

B

Starved cond.

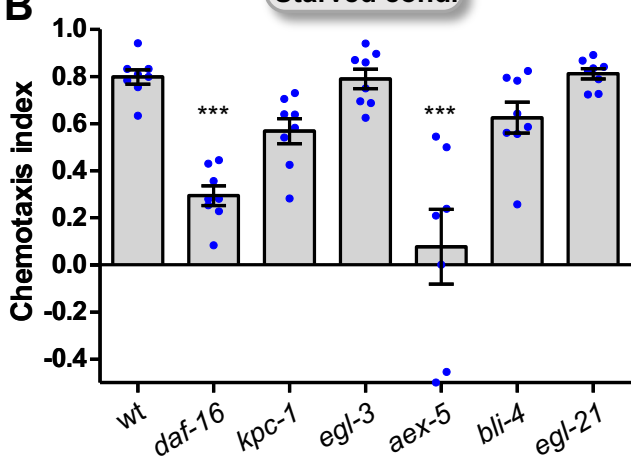

D

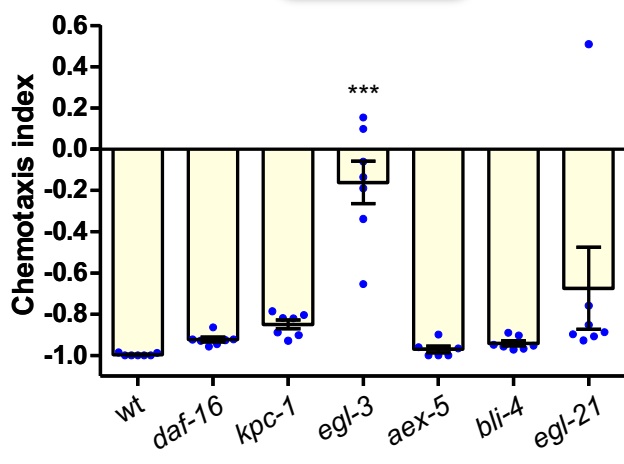

F

Fed cond.

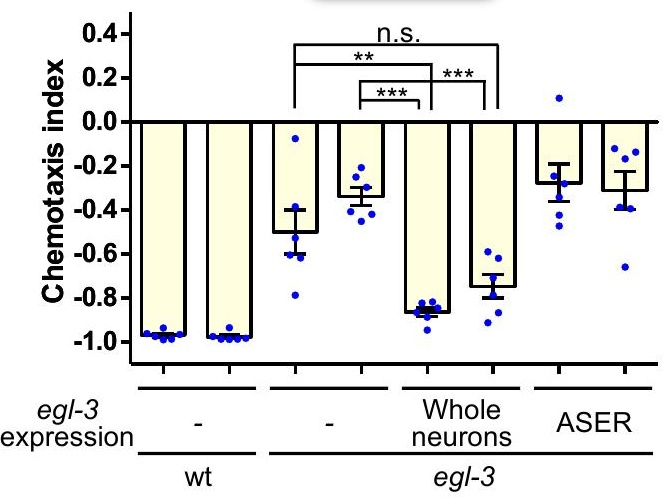

